\title{
1 Firm Productivity as an Engine of Saving
}

Saving rates are relatively low in Latin America and the Caribbean, as is productivity growth. Are these two facts related? Much of this book has argued that indeed, a relationship exists and that the direction of causality runs from savings to productivity, via investment. Low saving rates constrain investment in vital infrastructure such as roads, ports, and telecommunications, which in turn takes its toll on the growth of aggregate total factor productivity (TFP). Without the necessary infrastructure, firms cannot be fully efficient in the production process. Thus, low saving rates impede productivity growth and result in poor economic performance.

However, a second channel relates saving decisions to productivity growth and runs in the opposite direction. This chapter advances-and, more importantly, quantitatively assesses-the idea that productivity growth is not only a fundamental driver of long-run economic growth but, crucially, that it also constitutes an important determinant of saving decisions.

How does this connection from productivity to savings work? Essentially, it's through incentives. Individuals respond to incentives that convince them to postpone consumption today in order to save more and increase their well-being tomorrow. Economies with low TFP growth tend to be economies in which returns to investments are low. Faced with this prospect, firms have little incentive to invest-and households to save. Thus, saving rates will be low, too. In this way, low TFP growth, by providing weaker incentives to save, could be another determinant of the low saving rates observed in the region. The first half of this chapter explores the underlying mechanisms behind this idea, provides empirical evidence in favor of it, and quantifies the mechanism in some Latin American countries.

This causal link from TFP growth to savings is mediated by the financial system. Aggregate TFP is a weighted average of the productivity of individual firms. An economy in which productive firms can increase 
investment and hire more labor is an economy with high aggregate TFP growth. In order to invest, however, firms need access to financial markets. If instead, financial frictions constrain firms, some productive entrepreneurs may have to stay small until they can save enough to expand. Building up savings takes time; therefore, this process slows down aggregate productivity growth. The second part of the chapter looks at the distribution of private savings in the economy and at the behavior of firm saving in search of evidence that financial frictions distort the incentives to save in the region.

\section{From Japan to the World: The Empirical Link between TFP and Savings}

The role of productivity growth as an engine for saving has been well documented in the case of Japan in the 20th century. Chen, Imrohoroğlu, and İmrohoroğlu (2006) showed that the aggregate productivity growth between 1956 and 2000 in Japan explained most of the changes that took place in the country's saving rate during this period.

While the Japanese story is compelling, the real question is whether this pattern is apparent elsewhere around the world and at other points in time. An examination of the data contained in the Penn World Tables, an annual panel of 167 countries spanning the 1950 to 2011 period, provides further evidence of the relationship between saving and TFP growth. Focusing on separate episodes of surges in the saving rate strengthens the case even more. ${ }^{1}$

Episodes of high TFP growth have gone hand in hand with increases in saving rates. Considering 15 episodes of significant, sustained TFP growth; 11 of the 15 were accompanied by an increase in the saving rate as well. Panel a of Figure 10.1 illustrates this phenomenon by plotting TFP, real output per capita, and the saving rate during these episodes. Fifteen years later, on average, TFP had nearly doubled, output per capita had multiplied by a factor of 2.6 , and the saving rate had nearly doubled from around 12 percent to 22 percent. Importantly, the increase in the saving rate does not share the same timing as the other two variables, nor does it follow the same smooth path. Instead, the upturn in the saving rate occurs five years after the episode of TFP growth began.

While panel a supports the hypothesis that productivity can be an important determinant of savings, it does not imply that it is the only one. Panel b confirms a positive relationship between the two variables: 
on average, episodes in which TFP increased the most also enjoyed the greatest increases in the saving rate. Importantly, though, panel b also reveals that increases in TFP are not the only determinant of savings, nor are they a sufficient condition for boosting the saving rate. In four of the 15 episodes of significant TFP growth identified, the saving rate decreased.

\section{Figure 10.1 Episodes of Surges in TFP}

\section{a. Episodes of TFP Surges: Average Dynamics}

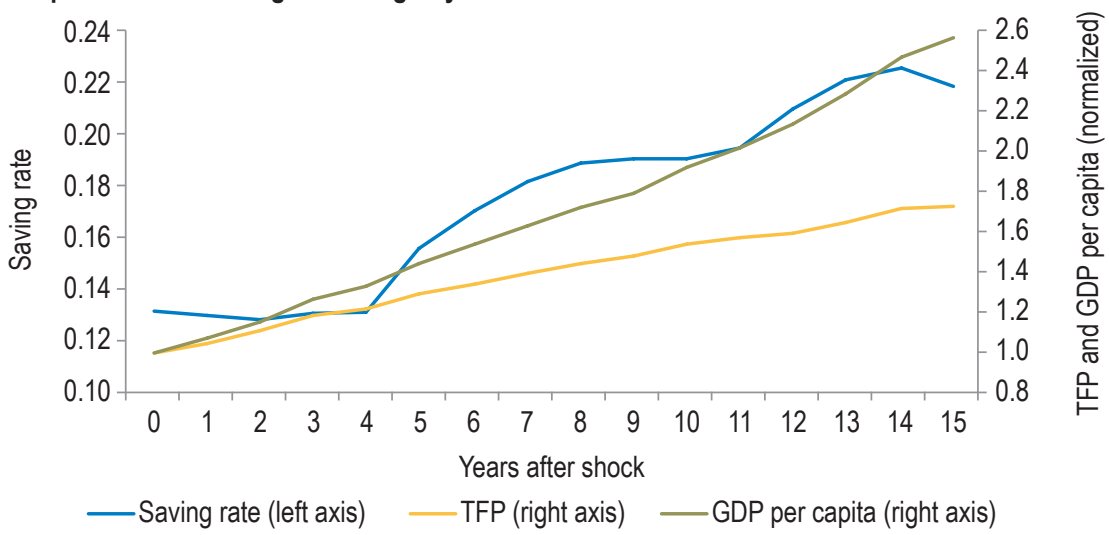

b. Episodes of TFP Surges: Changes in the Saving Rate and TFP

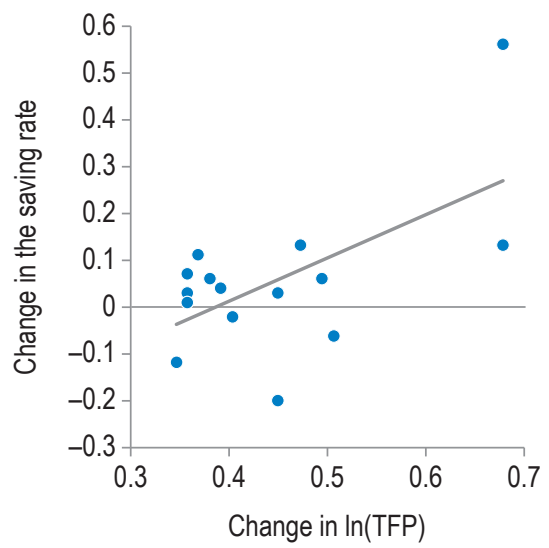

c. Episodes of TFP Surges: Changes in the Saving Rate and Initial Saving Rate

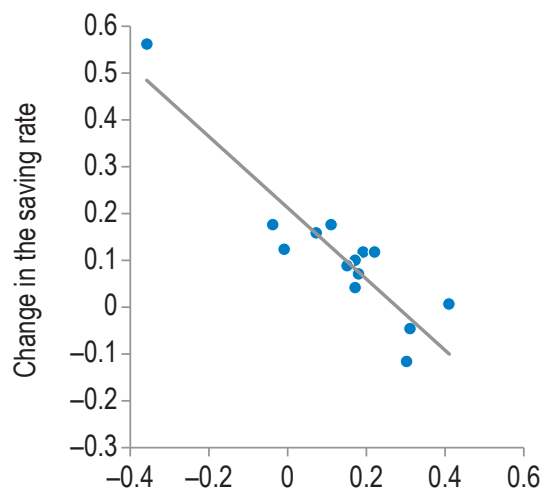

Saving rate at the beginning of the episode

Source: Authors' calculations and Penn World Tables.

Note: In panel a, numbers reported are averages across episodes. TFP and real GDP per capita are normalized to be 1 in the first year of the episode. The horizontal axis represents the years since each episode started. For a list of individual episodes and for methodological details for defining them, see Busso, Fernández, and Tamayo (2016). Panels b and c plot the change in the saving rate during the TFP episode against the change in (log) TFP and the initial rate at the beginning of each of the 15 episodes identified, respectively. The adjusted R-squared of the simple linear regression in panel $b$ is 0.31 and the positive slope has a coefficient of 1.05 with a p-value of 0.018 . The adjusted $\mathrm{R}$-squared of the simple linear regression in panel $\mathrm{c}$ is 0.82 and the negative slope has a coefficient of -0.84 with a $\mathrm{p}$-value of 0.001 . TFP = total factor productivity. 
Lastly, panel c presents the change in the saving rate in each episode against the level of the saving rate observed at the beginning of each episode. It reveals a strong negative relationship between the two variables: TFP episodes in which the change in the saving rate increased the most also had a lower saving rate at the beginning of the episode. The four episodes where the saving rate decreased when TFP surged were those with a relatively high saving rate to begin with-above 20 percent.

Another finding is that not all surges in saving rates end up boosting output per capita. Whether a saving rate surge is accompanied by increases in output per capita appears to be related to whether or not TFP increases. This relationship is illustrated in panels $a$ and $b$ of Figure 10.2, in which 22 episodes of large and sustained increases in the saving rate are analyzed. The episodes are divided into those in which TFP increased by less than 10 percent within a decade (panel a), and those in which it increased by at least that (panel b). In the episodes of saving surges characterized by high TFP growth, the saving rate tripled from 10 percent to almost 30 percent within 15 years, while TFP and income per capita increased by a factor of 1.4 and 1.2, respectively. By contrast, in episodes of saving surges characterized by low TFP growth, this variable essentially stagnated alongside income per capita.

This analysis teaches an important lesson: if saving and productivity can foster investment and growth, they should not be studied in isolation. The facts indicate that productivity growth is another important variable when trying to understand the behavior of saving and its contribution to economic growth and well-being. This conclusion is consistent with two empirically documented findings about Latin America: its low saving rates (see Chapter 2) and its persistently low productivity growth (Pagés, 2010).

\section{Incentives to Save}

Why do saving decisions depend on investment returns? The mechanism can be understood within the framework of the neoclassical growth model. It has two key building blocks. First, households decide how much to consume and how many hours to work in order to maximize their lifetime well-being. Second, firms combine capital and labor with varying degrees of technical efficiency (productivity). When capital is relatively scarce, firms will want to invest more, driving up the return to investment. Higher investment returns are then passed on to households, inducing them to postpone consumption and increase saving. Thus, saving 
Figure 10.2 Episodes of Surges in Saving Rates

\section{a. Episodes of Savings Surges with Low TFP Growth}

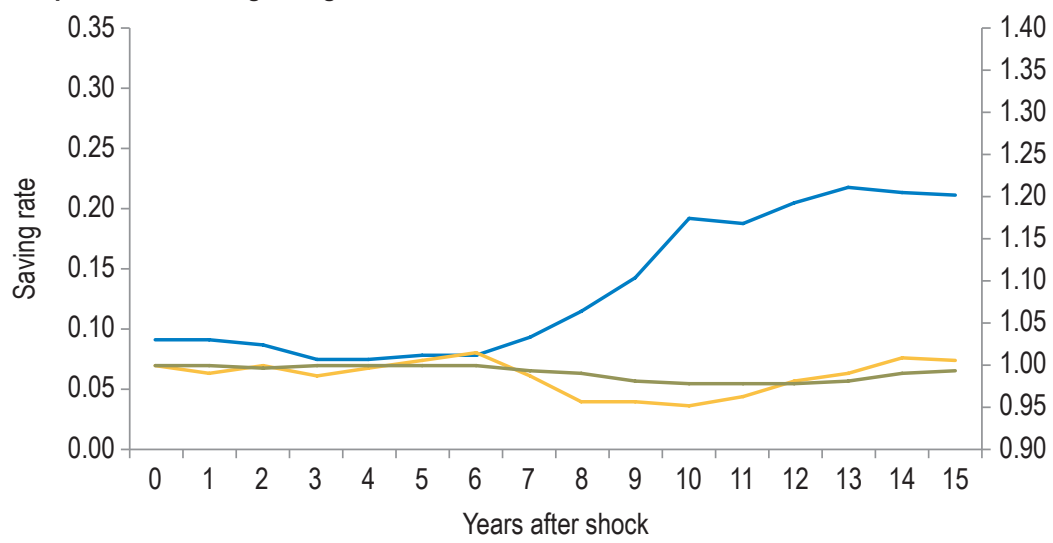

b. Episodes of Savings Surges with High TFP Growth

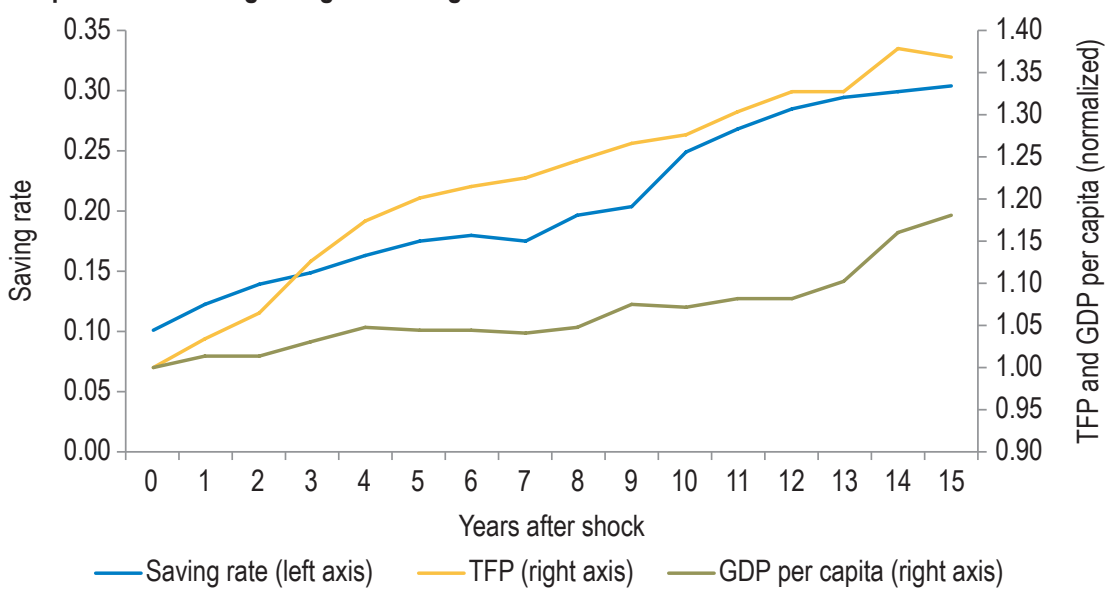

Source: Penn World Tables and authors' calculations.

Note: Numbers reported are averages across 22 episodes of saving rate surges. TFP and real GDP per capita are normalized to be 1 in the first year of the episode. The horizontal axis represents the years since each episode started. Panel a plots averages across 10 episodes in which TFP increased less than 10 percent within a decade. Panel b plots the remaining 12 episodes in which TFP increased by more than that. TFP = total factor productivity.

decisions are determined largely by the returns to investment, which in turn depend on several factors. One of these factors is TFP growth.

Consider the case in which individuals in an economy expect higher productivity growth. This implies that they will be able to extract increasingly larger amounts of output from each unit of capital, effectively increasing investment returns. In this case, individuals will postpone consumption today in order to save, invest, and reap the 
benefits of the increase in productivity when it comes. The economy's saving rate would increase above the level where it would otherwise have been. ${ }^{2}$ In addition to productivity, other factors may also affect returns to investment and saving behavior. First, higher depreciation of capital can reduce the net return of investing because a larger fraction of the capital invested is lost. Second, government taxation of capital income may reduce incentives to save as it reduces after-tax returns. Third, higher government consumption can also be an important drag on the resources available for saving. Lastly, higher population growth requires larger saving efforts in the long run. The relative importance of TFP growth as an engine for saving vis-à-vis these other factors is an open question. The next section quantifies how much each of these forces contributes to explaining the saving rate in three case studies, two of them from Latin America.

\section{Quantifying the Link from Productivity to Saving}

To quantify the impact of productivity growth on saving, Chen, İmrohoroğlu, and İmrohoroğlu (2006) use a version of the model described above, fitted to Japanese data. Saving rates are simulated feeding the model with the observed dynamics of TFP growth, as well as the other driving forces that can affect investment returns, namely, population growth, effective rates of capital taxation, and government consumption. The results from this exercise are presented in Figure 10.3 under the label "model with four driving forces." In addition, the figure presents two other simulated saving rates. One of these uses only the series of TFP growth and capital tax rates, leaving government spending and population growth constant ("model with TFP and taxes"). Finally, under the label "model with TFP," only the TFP growth series is used to simulate the saving rate, while keeping the remaining three forces constant. The main conclusion is that the simulated saving rate, using only the observed growth in productivity, properly tracks the evolution of Japan's observed saving rate.

Does this result hold in Latin America too? To answer this question, the model is fitted to Mexico and Chile, much as it was to Japan. These countries provide examples in the region of two contrasting experiences of productivity growth and saving rate dynamics. In Chile and Mexico, productivity suddenly rose and fell around the early-1980s "debt crisis." From the mid-1980s on, both productivity growth and the saving rate recovered in Chile but failed to do so in Mexico. 
In addition to actual TFP growth, the model is fed with tax rates, government consumption, and population growth, first jointly and then sequentially. The simulated saving rates for three different scenarios (i.e., the same as in the case of Japan) are reported in panels b and c of Figure 10.3, along with the actual saving rates. A few important observations emerge from the exercise.

\section{Figure 10.3 Neoclassical Model Predictions of Saving Rates}
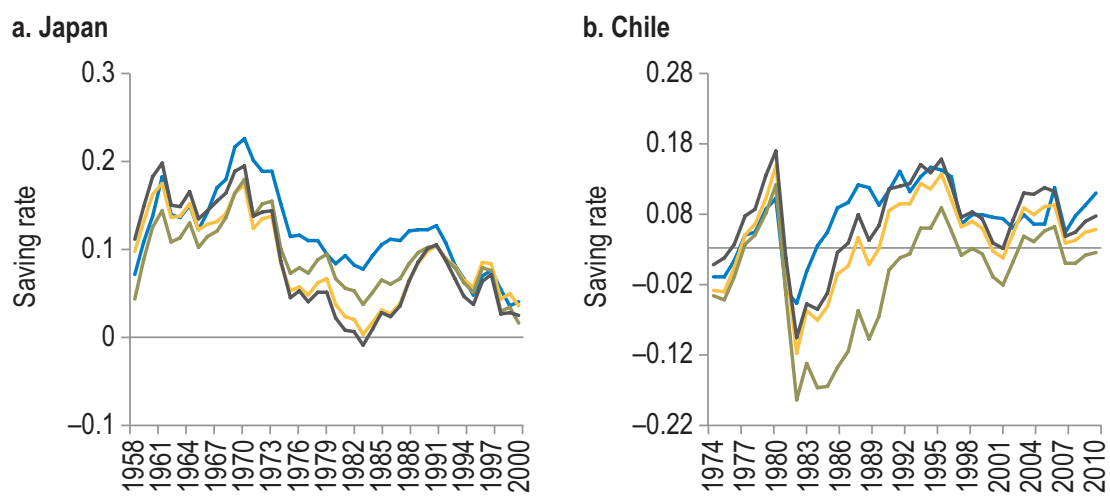

\section{c. Mexico}

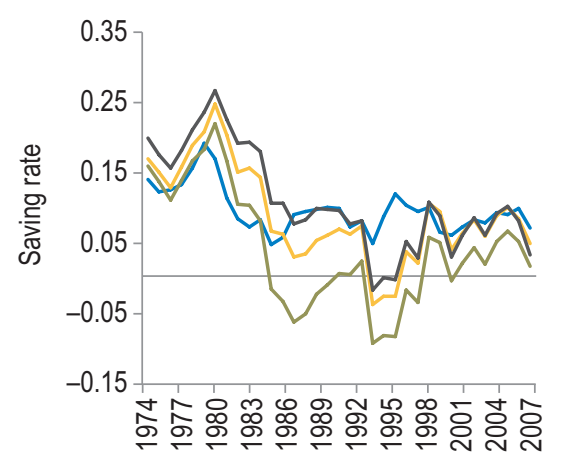

- Data

— Model with TFP

Model with TFP and taxes

- Model with four driving forces

Source: Authors' calculations and Chen, İmrohoroğlu, and İmrohoroğlu (2006).

Note: For Mexico, the parameterization of the model closely follows Kehoe and Meza (2011), who studied Mexico's growth experience during the post-war era. "model with four driving forces" = TFP growth, population growth, government consumption and a tax rate of 53 percent for 1970-88 and 22 percent thereafter. "model with TFP and tax reform" = government consumption and population growth at their sample averages but includes the 1987 "tax reform". "model with TFP" uses the pre-reform tax rate (of 55 percent) for the entire period. The rationale for including a significant drop in the tax rate comes from Mexico's major corporate tax reform in 1987 (Urzúa, 1993). In the case of Chile, the parameterization of the model closely follows Bergoeing et al. (2002). Given the lack of reliable data, capital tax rates were set at 55 percent between 1960 and 1987 and 12 percent thereafter (Bergoeing et al., 2002). Hsieh and Parker (2007) presented compelling evidence that corporate tax rates were lowered by these approximate magnitudes around 1986-87. 
First, in the case of Mexico, TFP growth and capital tax rates are able to track the actual saving rate fairly well. In particular, the model with only these two driving forces ("model with TFP and tax reform") is able to account for the rise and fall in the saving rate around the time of the debt crisis and for its subsequent stagnation. ${ }^{4}$ Second, while productivity growth helps account for the dynamics of the saving rates throughout this period, capital tax rates played an important role in explaining the saving rates leve/ in the aftermath of the debt crisis. In the model, capital tax rates serve as a proxy for the investment distortions in the economy. The results show that both TFP growth and these other investment distortions are required to track the evolution of the saving rate in Mexico.

In the case of Chile, the model predicts an increase and then a dramatic drop in the saving rate around the time of the debt crisis in the early 1980s. The series labeled "model with four driving forces" shows that the simulated saving rate can reproduce the major trends in the Chilean saving rate, perhaps even better than for Mexico. In sharp contrast to the Mexican case, in Chile, the saving rate climbed steadily in the years after the crisis and throughout the 1980s and early 1990s. To determine the main driver of this increase, Figure 10.3 compares three saving rates produced by the model. The results are that the strong TFP growth following the crisis of the early 1980s was the main driving force behind the observed saving behavior. ${ }^{5}$ Again, capital taxes (i.e., a proxy for broader investment distortions) are important in determining the level of the saving rate, perhaps to a larger extent than for Mexico.

To sum up, this analysis uncovers three main lessons. First, as in Japan, the dynamics of productivity help to explain the broad trends in the saving rates of Mexico and Chile. Second, the simulations for both Chile and Mexico support the hypothesis that saving incentives (i.e., investment returns) matter for saving decisions. Finally, and perhaps most importantly, other factors (i.e., investment distortions) play a more central role in explaining the level of saving rates in Chile and Mexico than in Japan. In the real world, these distortions go beyond capital taxes; they also include, for example, distortions in financial markets that raise the cost of credit for firms. There is plenty of evidence that investment distortions are pervasive in the region and should therefore command the attention of policymakers interested in boosting saving. 


\section{The Fine Print}

Even though the mechanism described above can help rationalize a causal link from productivity growth to saving, it has two potential limitations. ${ }^{6}$ First, the model assumes a closed economy setting. Productivity growth would matter less for national saving if countries could perfectly substitute national saving for foreign saving. In a small open economy, foreign capital should flow in with higher productivity growth in search of the higher returns to investment. Hence, investment would be decoupled from national saving. However, evidence of this decoupling has been elusive (see Feldstein and Horioka [1980], and Chapters 4 and 5). ${ }^{7}$

Second, a recent analysis finds that capital flows from rich to poor countries are not only low (as argued by Lucas, 1990), but their allocation across developing countries is at odds with the one predicted by the open economy version of the model described above (Gourinchas and Jeanne, 2013). Not only is the strong positive correlation between productivity growth and foreign capital inflows not observed in the data, in fact there is a negative correlation between the two-a phenomenon known as the "allocation puzzle."

Why doesn't capital flow to countries with higher productivity growth to take advantage of the higher returns to investment? Gourinchas and Jeanne (2013) argue that since individuals can save not only through physical capital but also through financial assets abroad, taxation of returns to physical capital offers an incomplete explanation to the pattern of national saving and capital flows. Instead, large distortions to the accumulation of wealth-saving-rather than to its allocation (between domestic physical capital and foreign financial assets) are responsible for the particular pattern of net capital flows in Latin America (as opposed to, say, countries in Asia that actually subsidize saving). This result validates the idea that in a closed economy a tax on capital income acts also as a tax on saving. It also reaffirms the importance of examining the investment distortions faced by firms in Latin America, an exercise undertaken in the second half of this chapter.

In addition, the model assumes that all firms are homogeneous. This entails studying consumption, labor, and saving decisions from the standpoint of a representative agent (i.e., without distinguishing between firms or households). In particular, who carries out saving decisions is immaterial in the sense that the same results are achieved regardless of whether firms or households save. Acknowledging that 
agents vary along several dimensions-for instance in terms of wealth and productivity-has two important implications. First, aggregate productivity growth now results from combining the levels and growth rates of individual productivities of all operating firms at a given point in time (see Busso, Fernández, and Tamayo, 2016). Second, the efficient allocation of capital requires institutional arrangements, such as financial markets, for savings to flow across firms and sectors toward their most productive use. That is, with heterogeneous agents, who saves and how much matters. ${ }^{8}$ For this reason, the rest of this chapter focuses on heterogeneity and distortions in saving-investment decisions.

\section{Zooming in on Firms' Saving Decisions}

Since entrepreneurs, by nature, vary in terms of their ideas and abilities to organize production, firms in the economy have different levels of productivity. Who gets to produce, and how much, matters for aggregate productivity. If a highly productive entrepreneur faces numerous obstacles in financial markets (also known as financial frictions) and thus cannot obtain the credit necessary to fund projects, the firm's growth will be constrained dramatically, as it will need time to accumulate internal funds. This results in lower long-run aggregate productivity growth.

As discussed earlier, low productivity growth provides few incentives for the economy to save. However, while financial frictions hinder productivity growth and thus result in lower aggregate saving, they nonetheless induce productive firms to save (i.e., accumulate internal funds) in order to overcome the lack of access to credit markets; therefore, paradoxically, financial frictions result in a higher share of saving in the economy done by firms (rather than by households). Analyzing the distribution of private saving in the economy, as well as patterns of firm saving, provides evidence that financial frictions distort price signals and incentives to save.

Why do firms save? ${ }^{9}$ To begin with, firms must regularly meet cash needs for the ordinary course of business. Since it is costly to convert noncash financial assets regularly into cash for payments, firms need to hold cash to make those payments. Besides this transaction motive, there is a precautionary motive: businesses save so they can react more rapidly to adverse shocks or investment opportunities when access to capital markets is costly or takes time. Finally, and perhaps more importantly, firms save to finance current and future investment. 
In contrast to households, which decide to save to increase future consumption, firms decide how much to save and invest to maximize their profits based on the relative costs of internal versus external funding sources.

In an economy without any transaction, bankruptcy, or agency costs, without any distortionary taxes, with symmetric information, and with efficient markets, the capital structure of the firm would be irrelevant for the firm value (Modigliani and Miller, 1958). In such an ideal economy, firms would have no reason to save. If they needed funds to build new plants, buy new machinery, or weather unexpected drops in sales or surges in expenses, they could borrow money from lenders and repay debts in the future. In such an economy, the cost of borrowing (the interest rate) would be the same as the cost of internal funds. In a world with symmetric information, banks, knowing everything that the firm does, would provide those resources if the firm were to find it profitable in the long run; otherwise, the firm would not be willing to borrow money in the first place.

The real world, however, is littered with transaction, bankruptcy, and agency costs; there are distortionary taxes and information frictions; and markets can be inefficient. For the sake of simplicity, these impediments are referred to as "financial frictions." These frictions make external financing relatively more costly than internal financing, thereby increasing incentives for firms to save rather than borrow money from lenders. Information frictions can prevent firms that want to borrow money from finding willing lenders, for whom it is costly to determine the viability of investment projects. This raises the cost of external finance and encourages firms to save. The so-called pecking order theory of finance (Myers and Majluf, 1984) predicts that based on firms' relative cost, it is best for them to use their own savings first, then to use debt, and finally, as a last resort, to issue equity.

Thus, the share of private saving done by firms can be rather large in most economies. Figure 10.4 shows the share of business saving to total private saving computed using national account data (Bebczuk and Cavallo, 2016). It plots information for a subset of countries in Latin America for which data are available, and for three comparison regions/ countries: core Europe, the United States, and Germany. Businesses in all regions/countries under consideration are responsible for more than 50 percent of private saving, including Latin America, where the share of private saving by firms is 68 percent. 
Figure 10.4 Share of Corporate Saving in Private Saving

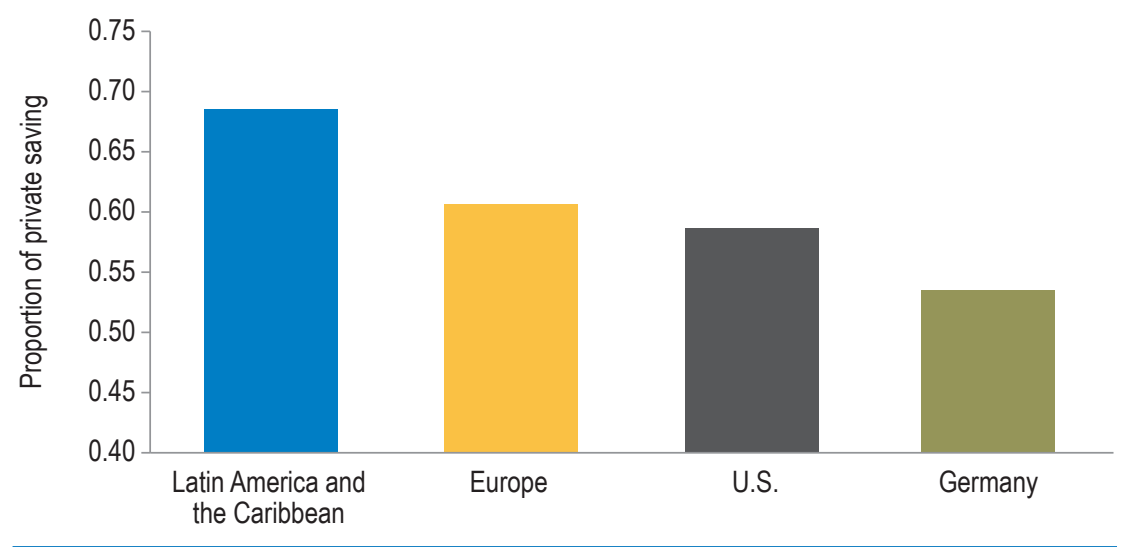

Source: Authors' calculations based on Bebczuk and Cavallo (2016).

Note: Latin America and the Caribbean refer to Brazil, Chile, Colombia, Ecuador, Guatemala, Honduras, and Mexico. Europe refers to Austria, Belgium, France, Italy, the Netherlands, Portugal, Spain, Switzerland, and the United Kingdom. Data are for 2008-12. Private saving is the sum of household and corporate saving.

In most economies, the average firm funds a large proportion of its investment projects using its own saving. Firms in Latin America follow this norm, funding between 45 and 75 percent of their capital with their own savings (see Figure 10.5). Even in Germany, a country with a more developed financial system, the average firm finances 44 percent of its fixed assets with its own savings. ${ }^{10}$

Why do firms in certain economies seem to rely more heavily on their own savings to fund their capital stock? One likely explanation is that their financial systems are underdeveloped. Firms that face fewer binding financial constraints rely less on internal funds to finance their capital investment. They usually face less stringent collateral requirements (Beck, Demirgüç-Kunt, and Maksimovic, 2005, 2008) and, given their size, are typically subject to less severe information asymmetries, resulting in multiple sources of funding (Diamond and Verrecchia, 1991). Figure 10.6 shows that the share of internal funds to finance capital declines with size; it is smaller for larger, less financially constrained firms.

Figure 10.7 utilizes a more direct measure by analyzing actual access to credit. In the scatter plot, each dot represents a country and size category combination. This figure confirms that the greater the access to credit, the smaller the share of investment financed with saving.

Financial frictions seem to be a particularly acute problem in Latin American economies, where financial development is low. Fernández and 


\section{Figure 10.5 Firms' Financing with Their Own Savings, Germany and Select Latin American and Caribbean Countries}

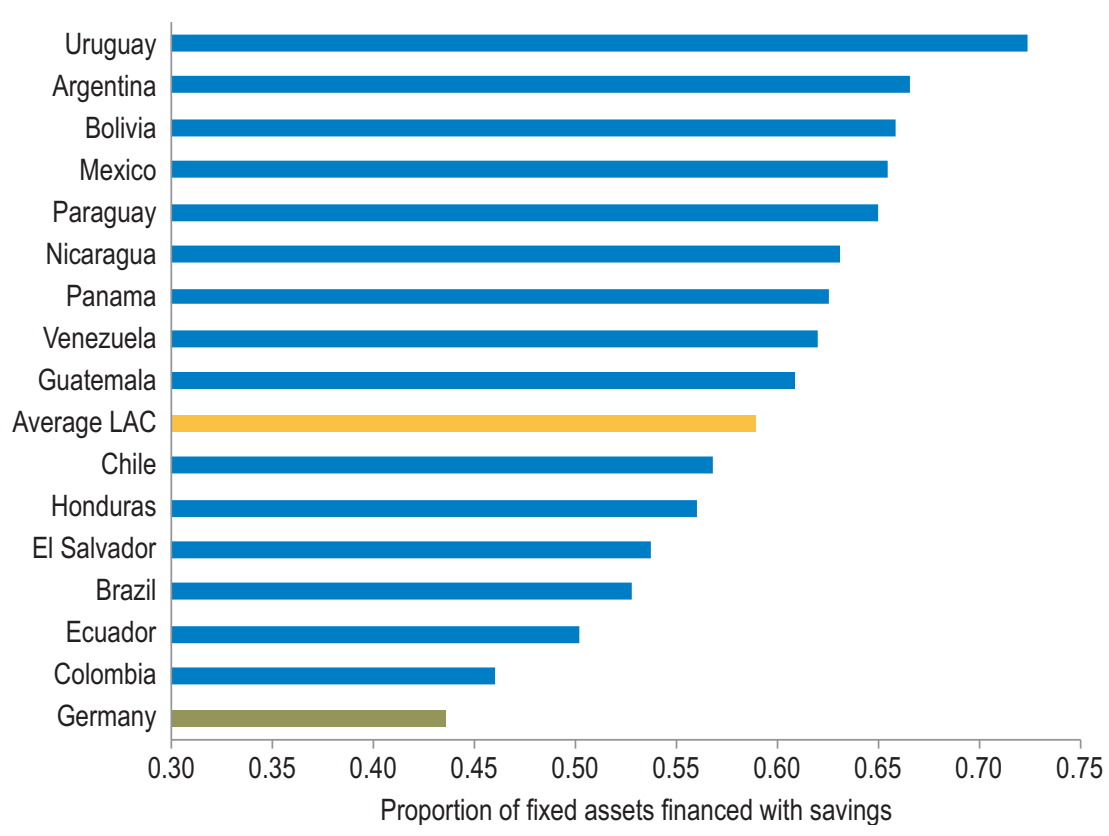

Source: Authors' calculations based on World Bank Enterprise Survey (WBES). See Busso, Fernández, and Tamayo (2016) for details.

Note: Firm savings are defined as internal funds or retained earnings. LAC refers to Latin America and the Caribbean.

Figure 10.6 Share of Fixed Assets Financed with Savings, by Firm Size

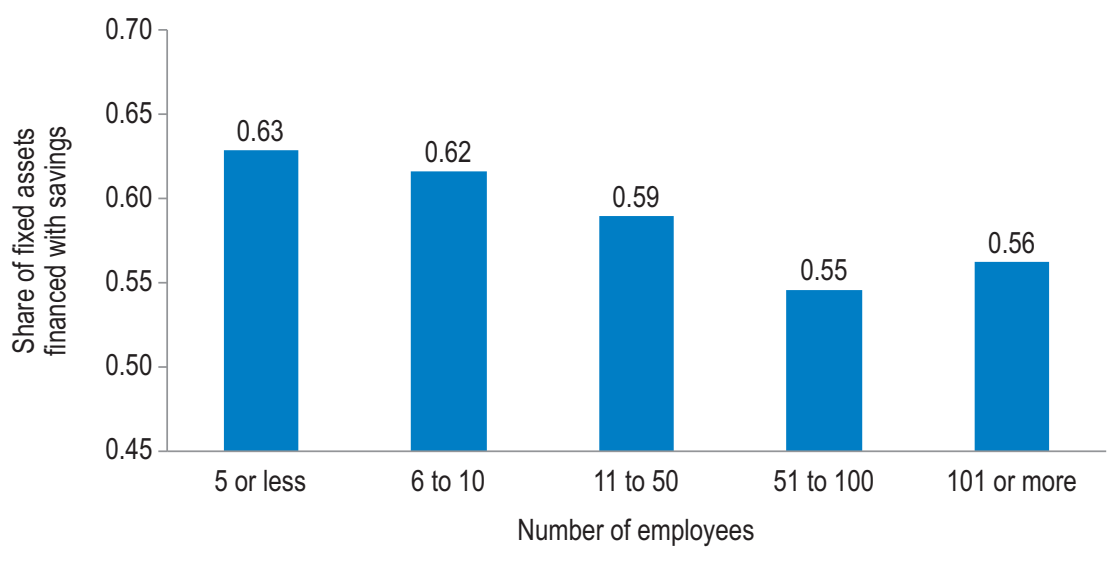

Source: Authors' calculations based on World Bank Enterprise Survey (WBES). See Busso, Fernández, and Tamayo (2016) for details.

Note: Firm savings are defined as internal funds or retained earnings. 
Figure 10.7 Fixed Assets Financed with Savings and Access to Credit

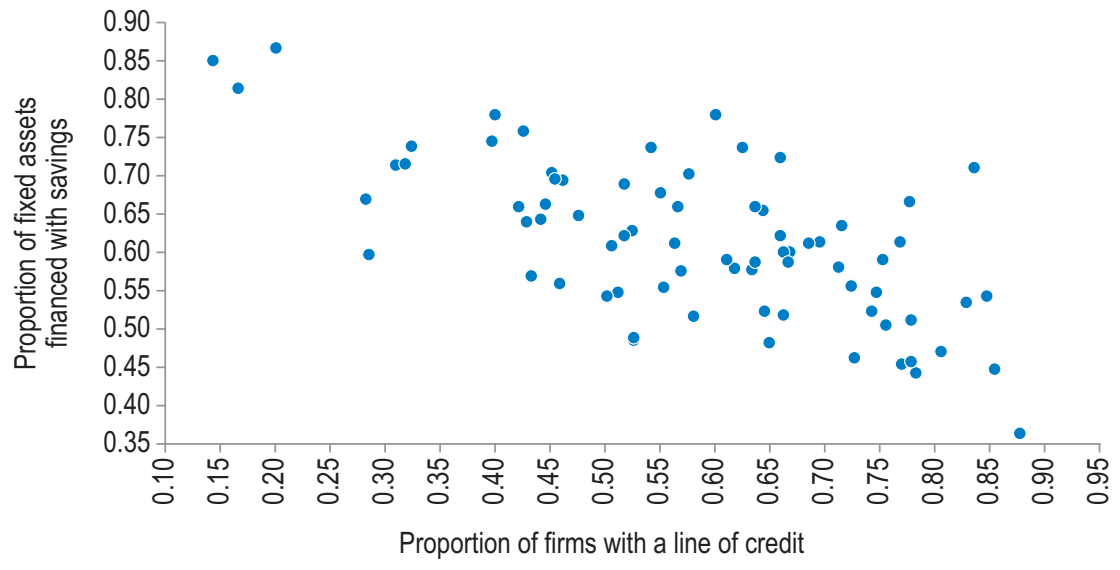

Source: Authors' elaboration based on World Bank Enterprise Survey (WBES). For a list of countries and other details, see Busso, Fernández, and Tamayo (2016).

Note: Each dot represents a country-bin size combination.

Tamayo (forthcoming) survey the institutional causes of financial underdevelopment and their effect on growth. They pay particular attention to the weak institutions in Latin America which result, for example, in poor creditor protection. Importantly, low financial development could have been a bottleneck in the process of resource reallocation following the large-scale reforms implemented by many countries in the region in previous decades.

\section{Firm Saving: A Way Out for Productive Firms}

Firm saving is an imperfect remedy for financial underdevelopment. Saving can help firms overcome financial frictions so they can grow. In this way, saving is related to firm-level productivity and aggregate TFP growth. Firms usually start on a small scale with ideas, low levels of capital, and only a few employees. Small firms learn to organize their business and practices, and with time, realize whether they are productive or not. Not all firms, however, are born equal.

Small, unproductive firms have low marginal products of capital and labor. They have no reason, need, or ability to expand. Depending on how much competition and price distortion they face in their sector, they can survive with low levels of capital. Consequently, they find no need to save much. Their probability of exiting the market in which they operate in any given year is high (Davis, Haltiwanger, and Schuh, 1996). In Latin 
America, these firms are usually small, informal, family-owned enterprises that survive mainly because distortions allow them to pay lower input costs or to charge higher prices.

For small, productive firms, however, it is optimal to grow by hiring more labor and acquiring more physical capital. This process of firm growth usually requires long-term investments in the form of new and larger plants that imply substantial resources, and which pay off only gradually over time. Even if the sunk cost of investment is tiny relative to the potential stream of future profits, the firm could expect costs to be very high compared to the meager profits from a small plant. Saving for future investments could be the only way to grow-and this process could take a long time.

Therefore, financial frictions have implications both for aggregate TFP growth and for the level and type of saving done in the economy. To understand why, firms can be classified into three types: small, unproductive firms that remain small or eventually exit the market; small, productive firms that would like to grow but cannot because of financial constraints; and firms that have already jumped to a larger scale.

In an economy with few financial frictions, small, productive firms can borrow substantially to upgrade their plants. Large firms invest to maintain their physical capital. Small, productive firms grow fast, increasing demand for capital and labor, which translates into higher wages and returns to capital accumulation. These price changes have many implications. First, higher wages eventually convince some small, unproductive entrepreneurs to close their plants and become wage employees. Therefore, such an economy has a significant share of large firms. Because productive firms grow fast, the share of small, productive firms is minimal, and there are almost no small, unproductive firms. Since the total factor productivity of the economy is a weighted sum of the productivity of individual firms, this economy enjoys higher aggregate productivity growth. Moreover, higher (equilibrium) investment returns translate into higher incentives for individuals to save. Aggregate savings are higher too.

Now consider an economy with high financial frictions, assuming the same distribution of firm productivities as before. Small, productive firms cannot borrow to upgrade plants and must save a larger portion of the required resources; therefore, they remain small longer. They do not increase labor demand, and wages remain low. They also do not increase demand for capital, and returns to capital accumulation remain low, as well. In such an economy, the mix of firms is very different. There 
is a smaller share of large firms, a larger share of small, productive firms that want to grow but cannot, and a larger share of small, unproductive firms. Aggregate productivity growth and aggregate savings are lower. The ratio of firm-to-household savings is higher because saving is the only way for firms to upgrade their plants. In that sense, excessive firm saving signals an underdeveloped financial system.

On average, more productive firms tend to save more. More importantly, productive firms without access to credit tend to save more than unproductive firms (see Busso, Fernández, and Tamayo, 2016). This correlation is even stronger among firms that applied for credit but did not secure it yet. In other words, holding the size distribution constant, more productive firms tend to save more. They require capital to grow but cannot access credit.

There is a relatively large, recent literature that formally models the relationships between financial frictions, firm productivity, saving, and aggregate TFP growth along the lines outlined above. For example, Midrigan and $\mathrm{Xu}$ (2014) use firm-level data to calibrate a model to South Korea (an economy with low financial frictions), China, and Colombia (two economies with high financial frictions). They show that without firm saving, the costs of financial underdevelopment would be much greater. Financial imperfections have a negative effect on the number and scale of producers that operate in the economy. The ability of firm saving to allow small firms to grow is more limited, precisely because their saving capacity is low. ${ }^{11}$

\section{A Productive Approach to Policy}

Two general policy implications are clear. First, when considering policies to promote savings, policymakers should not overlook economic reforms that foster productivity growth. It is no coincidence that episodes of fast TFP growth have been accompanied by increases in the aggregate saving rate and GDP growth, while episodes of savings growth without TFP growth did not lead to GDP growth. There is a reinforcing link whereby more saving can increase growth only if the additional savings is invested in projects that generate high returns and thus enhance productivity growth. Unfortunately, productivity growth has been elusive in Latin America. Policies to promote productivity growth in the region, including those aimed at improving the allocation of resources, promoting competition, and fostering firm innovation, are discussed in Pagés (2010). 
Second, since aggregate productivity is a weighted average of the productivity of individual firms, which firms get to produce and how much affects the resulting aggregate productivity growth, and is therefore crucial for generating saving incentives. In particular, severe financial market frictions slow down the dynamics of productive firms significantly, as these firms need to save before they can grow. While this allows productive firms to save more, it also results in losses due to resource misallocation, lower TFP growth, and lower aggregate saving rates. Moreover, labor market and product market distortions might interact with the distortions generated by financial frictions and exacerbate the productivity cost of financial underdevelopment (these interactions are explored in Box 10.1).

Thus, policies to address the underlying causes of financial frictions (which is the focus of the next chapter) can help improve capital allocation, thereby increasing investment returns and saving incentives. In the search for more and, particularly, better saving in Latin America and the Caribbean, alleviating financial frictions can have a quantitatively significant impact.

\section{BOX 10.1. FIRM SAVING, INFORMALITY, DISTORTIONS, AND MISALLOCATION}

Latin America has a large number of small, informal, and unproductive firms that face lower costs of inputs or higher product prices because taxes and regulations are not properly enforced (Busso, Fazio, and Levy, 2012). By distorting prices, informality can provide incentives for unproductive firms to grow, even when they would not do so otherwise. The economic inefficiencies generated by these labor and tax distortions can be amplified by the ability of firms to save.

Consider a household that owns a small and relatively unproductive firm, and thus extracts little output from labor and capital. Suppose only labor market distortions exist. This informal firm is less productive than a formal firm in the same sector; it does not pay labor taxes, and therefore it has lower labor costs. For simplicity, assume capital is a complement to labor. Both firms hire labor and capital until the marginal products of these inputs equal their cost. The informal firm, facing lower labor costs, would hire more labor and capital than if resources were efficiently allocated. In an economy with financial frictions, the informal firm is likely to face higher external funding costs than the formal firm. These financial market distortions lessen the misallocation caused by labor market distortions.

This argument ignores the fact that entrepreneurs can overcome financial constraints through saving. If there were financial frictions and no labor mar- 
BOX 10.1. (continued)

ket distortions, then small, informal, unproductive firms would have no reason to save because it would not be optimal for them to grow. However, with labor market distortions, their labor costs would decline, and it could potentially be in the interest of these firms to save in order to acquire capital (which complements labor).

Thus, in a context of preexisting distortions, firm saving can create an additional inefficiency by allowing small, informal firms to work around financial restrictions, and therefore capture more resources (labor and capital) than they would otherwise. Without those preexisting labor distortions, this inefficient cost of savings would not be a factor. Increasing aggregate productivity by reducing misallocation requires reducing preexisting distortions rather than preventing firms from saving, which is probably not feasible.

The additional misallocation cost of firm saving depends critically on the actual amount of capital allocated to small, informal, and unproductive firms and on the shape of these firms' demand for capital. The evidence suggests that this is not a first-order problem, however. In order to estimate the size distribution of capital in the economy, an economic census that covers all firms in that economy is needed. The only country in the region that has such data is Mexico. Busso, Fazio, and Levy (2012) use Mexico's 2008 economic census and find that 90 percent of establishments have fewer than five employees and employ 38 percent of the economy's labor, but only 13 percent of the capital. On the other hand, larger firms with 50 or more employees employ more than 70 percent of the economy's available capital. Data from the National Survey of Microenterprises for Mexico confirm that small firms do not use much capital: the median small firm has a stock value of capital of less than US $\$ 1,000$. This is consistent with experimental evidence that finds that small, informal firms have a marginal product of capital that is very high for very low levels of capital (de Mel, McKenzie, and Woodruff, 2008) and decreases sharply as firms accumulate small amounts of capital (McKenzie and Woodruff, 2006).

Thus, even though labor and tax distortions are large and can misallocate resources-thereby exacting a high toll on productivity in developing countries (Hsieh and Klenow, 2009; Restuccia and Rogerson, 2008)-they do not seem to increase because of firm saving. 


\section{Notes}

1 See Busso, Fernández, and Tamayo (2016) for further details about the data and methodology used in this section, the specific criteria used when identifying these episodes, as well as a complete list of them.

2 Busso, Fernández, and Tamayo (2016), which serves as an online appendix to this chapter, presents a full mathematical description of how the neoclassical model works, as well as a simulation following an expected future increase in productivity.

3 Both Mexico and Chile suffered severe debt and financial crises during this time that manifested in collapses of productivity, which the exercise is going to take as given. The main goal is to assess how these events determined the saving decisions during this period.

4 However, when compared to model performance in Chen, Imrohoroğlu, and İmrohoroğlu (2006), the model appears to miss some shortrun dynamics. This is expected, given the superior data with which Chen, İmrohoroğlu, and İmrohoroğlu (2006) were able to work. These authors had complete times series of capital tax rates and carefully constructed depreciation series from Hayashi (1989).

5 Cerda et al. (2015) show that a precipitous decline in tax rates on retained earnings (from close to 50 percent in 1985 to 10 percent in 1988) provided plenty of saving incentives in those years.

6 There are also alternative explanations for the link between productivity growth and savings. In fact, Aghion et al. (2009) postulate that low productivity itself may be reinforced by low national saving rates. According to their model, growth in poor countries results from innovations that allow local sectors to catch up with the technology frontier. However, doing so requires the cooperation of a foreign investor who is familiar with the frontier and a domestic entrepreneur who is familiar with the local conditions. National savings allow the local entrepreneur to take an equity stake in this cooperative venture, thus mitigating potential agency problems.

7 Chapter 5 provides evidence about the imperfect substitutability between national and foreign saving. In addition, de la Torre and Ize (2015), who argued for the presence of transaction costs that would make foreign and domestic savings imperfect substitutes, have recently confirmed this for Latin America. 
8 Notice that, with perfect financial markets, heterogeneity has no real effect since all firms could freely borrow to quickly attain their optimal size. Likewise, imperfect financial markets without heterogeneity revert back to the neoclassical world (see Busso, Fernández, and Tamayo, 2016).

9 See Bebczuk and Cavallo (2016) for a complete treatment of this issue.

10 This result is similar to the one presented in Kawamura and Ronconi (2015). The main difference is that in this chapter, data from the WBES is reweighted in order to keep constant the size distribution of firms across countries. This is done to prevent differences in the sampling frame of each country from affecting the results. See Busso, Fernández, and Tamayo (2016) for more details.

Buera, Kaboski, and Shin (2011) use a similar model to explain the relationship between aggregate total factor productivity and financial development across countries. They assume that after production, entrepreneurs could renege on borrowing contracts. This imperfect enforceability of contracts introduces a financial friction that distorts the allocation of capital across firms and their entry/exit decisions, reducing aggregate productivity growth. In their model, forward-looking self-financing (i.e., saving) can alleviate the resulting misallocation. However, it is more difficult to self-finance on a larger scale with larger financing needs. Thus, large-scale sectors (such as manufacturing) are affected more by financial frictions than smaller-scale sectors (such as services). The variation in financial development explains 80 percent of the difference in output per worker between Mexico and the United States.

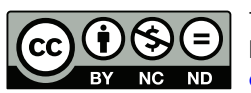

This chapter is distributed under the terms of the Creative Commons Attribution-NonCommercial-NoDerivatives 3.0 IGO license (http://creative commons.org/licenses/by-nc-nd/3.0/igo/) and may be reproduced with attribution to the Inter-American Development Bank (IDB) and for any non-commercial purpose. No derivative work is allowed.

Any dispute related to the use of the works of the IDB that cannot be settled amicably shall be submitted to arbitration pursuant to the UNCITRAL rules. The use of the IDB's name for any purpose other than for attribution, and the use of IDB's logo shall be subject to a separate written license agreement between the IDB and the user and is not authorized as part of this CC-IGO license. Note that the link provided above includes additional terms and conditions of the license.

The images or other third party material in this chapter are included in the work's Creative Commons license, unless indicated otherwise in the credit line; if such material is not included in the work's Creative Commons license and the respective action is not permitted by statutory regulation, users will need to obtain permission from the license holder to duplicate, adapt or reproduce the material. 